\title{
PERCEIVED COHESION IN MILITARY STUDENT GROUPS
}

\author{
Crenguța Mihaela MACOVEI \\ "Nicolae Bălcescu" Land Forces Academy, Sibiu, Romania \\ mihaela.macovei1@gmail.com
}

\begin{abstract}
The purpose of this study is to examine the psychometric structure of the Perceived Cohesion Scale (PCS). For this, we applied that scale version that was adapted by Chin, Salisbury, Pearson, \& Stollak for small groups because we considered that the formulation of the items is very well suited to the type of group represented by the military student platoon. The results of our study support the two-factor structure of the scale proposed by its authors. Both identified factors have demonstrated adequate levels of reliability. This scale proves to be a useful tool in measuring the cohesion of military student groups.
\end{abstract}

\section{Keywords: perceived cohesion, military students}

\section{Introduction}

The way in which cohesion emerge and develops depends on the nature of the social groups and the context in which they evolve [1]. Cohesion is considered a "critical group variable" [2] affecting group performance [3],[4], organizational justice and affective commitment [5], and organizational citizenship behaviour [6],[7]. In the military domain the cohesion of the group was correlated with the level of the morale, with the presence of ésprit de corps and trust, coordination, cooperation and communication as determinants of primary military teams performance - sections and platoons [8].

MacCoun and Hix [9] have published an extensive review of empirical studies conducted during 1993 - 2010 on group cohesion. The authors show that the studies under consideration have highlighted two main types of cohesion: horizontal cohesion and vertical cohesion.

Horizontal cohesion consists of two distinct types of cohesion - task and social cohesion described as follows: "Task cohesion is the shared commitment among members to achieving a goal that requires the collective efforts of the group. A group with high task cohesion is composed of members who share a common goal and who are motivated to coordinate their efforts as a team to achieve that goal. Social cohesion is the extent to which group members like each other, prefer to spend their social time together, enjoy each other's company, and feel emotionally close to one another" [10].

Task and social cohesion as forms of horizontal cohesion appear at the primary group level - crew, squad or platoon. Vertical cohesion involves leaders and their followers - this is the reason why we use terms like leadership or followership, as they appear in organizational studies. Salas, Grossman, Hughes \& Coultas [11] have identified three other sub-dimensions of cohesion:

- Belongingness: "The degree to which members of a group are attracted to 
each other", is a sub-dimension highlighted by M.E. Shaw in 1981;

- Group pride: "The extent to which group members exhibit liking for the status or the ideologies that the group supports or represents, or the shared importance of being a member of the group", is a subdimension identified by Beal, Cohen, Burke, \& McLendon in 2003;

- Morale: "Individuals' high degree of loyalty to fellow group members and their willingness to endure frustration for the group", is a sub-dimension identified by Cartwright \& Zander in 1960.

\section{Cohesion in military groups}

MacCoun and Hix [12] list the factors underlying the cohesion of military groups:

- propinquity (spatial and temporal proximity)

- shared group membership

- attitude similarity

- success experiences

- shared threat

- leadership and training

These factors begin to exert their influence on individuals from the initial training period. In one of the seminars of the Military Psychology Course at the Land Forces Academy in Sibiu, students were asked to write an essay individually in order to analyze the cohesion of the platoon they are part of, using the above information on the subject; the information was presented and explained during courses. These essays highlighted the fact that, beyond the real level of cohesion that can be measured by instruments with a lower or higher degree of objectivity, there is a personal perception of the cohesion of the military student group. This perception is influenced by several factors that concern both the individual and the group. This is the reason for which we considered that the Perceived Cohesion Scale (PCS) is a suitable tool for measuring cohesion in this type of group.

The Perceived Cohesion Scale (PCS) was applied, separately, in each I ${ }^{\text {st }}$ year platoon in December 2017. Ten platoons responded to the questions of this scale; the smallest platoon is made up of 20 students and the largest platoon consists of 27 students. The composition of platoons is heterogeneous, each of them being made up of girls and boys alike, graduates of military and civilian high schools, but the composition is not identical in all ten platoons analyzed. The scale was applied five months after the platoons were formed; this means that students had had five months to get to know each other, to interact, to carry out various types of tasks together.

Admission to the academy is followed by a six-week period in which students, already grouped in platoons, start basic military training modules. These modules are perceived by each student, without exception, as very difficult. For military high school graduates the impact is not as tough as it is for civilian high school graduates; as a matter of fact, the former often become a support for the students coming from civilian environment and act as a focal point for group cohesion, providing support and help to those who have difficulty adapting to this period of intense initial training.

From the point of view of cohesion, this period remains a reference point for students because the tasks they have to solve require them to cooperate and, above all, to rely on one another. Platoon commanders consciously seek to start and develop cohesion. In his essay, a student made a description of this period that very well synthesizes what his colleagues wrote in their essays: "We went through many things together, such as physical exhaustion, lack of sleep, we froze together, we were hungry after training, we were punished together for not following orders, but I know that more challenges are to come. As a result of these obstacles, our relationship has strengthened, we have become more agreeable to each other, and e have easily learned to accept one another." After this sudden immersion in military student life, students begin the theoretical 
and practical training modules inside the academy. Tasks change and so does the way they are approached; teachers and military instructors share individual tasks and perform assessments of each student's work. This type of approach tests the freshly built cohesion of each platoon. Relationships change, students interact from other positions, new alliances are created, and new conflicts arise from other reasons. The physical and temporal proximity generated by students' sharing dormitories creates groups with a higher degree of cohesion, which puts additional pressure on the cohesion of the platoon as a whole. During this period, platoon commanders must make an extra effort to build the social cohesion of the platoon.

As a conclusion, we are quoting a student who writes in the essay: "When I came to the academy and the platoon was formed, nobody knew anyone. As a result, cohesion was completely absent. After about three weeks, we began to make friends, to help and trust each other. The military environment not only makes you stay with other people, but also brings you and your friends close together, and makes your friendship stronger. In this environment, you spend more time with your colleagues than with your family. Consequently, although you may not like every person in this group you must at least accept them. Social cohesion is possible, but only with some people; with other people, only task cohesion is possible."

\section{Perceived Cohesion Scale}

Bollen and Hoyle [13] consider that the perception of group members regarding the cohesion of their group has significant effects on their behavior, as well as on the behavior of the group as a whole. They have created a scale to measure perceived cohesion in groups - Perceived Cohesion Scale (PCS) - which was tested in two random samples: students at a small college and residents of a midsized city. Following confirmatory factor analysis they identified a two-factor model with two highly correlated dimensions - sense of belonging and feelings of morale.

Chin, Salisbury, Pearson \& Stollak [14] adapted this scale so that it can be used to measure cohesion in small groups. Their study confirmed the two-dimensional structure of the scale identified by Bollen and Hoyle. Also, Salisbury, Carte \& Chidambaram [15] found a good validity, reliability and factorial stability of Perceived Cohesion Scale in their study on the cohesion of virtual teams.

In our study we used the items that Chin et al. used in their study published in 1999 . These items are shown in Table 1 (English and Romanian version).

Table1. Perceived Cohesion Items

\begin{tabular}{|l|l|}
\hline 1 & $\begin{array}{l}\text { I feel I belong to this group. (belong1) } \\
\text { (Simt că aparțin acestui grup.) }\end{array}$ \\
\hline 2 & $\begin{array}{l}\text { I am happy to be part of this group. (morale1) } \\
\text { (Sunt fericit( } \breve{a} \text { ) să fiu o parte a acestui grup.) }\end{array}$ \\
\hline 3 & $\begin{array}{l}\text { I see myself as part of this group. (belong2) } \\
\text { (Mă văd ca parte a acestui grup.) }\end{array}$ \\
\hline 4 & $\begin{array}{l}\text { This group is one of the best anywhere. (morale 2) } \\
\text { (Acest grup este unul dintre cele mai bune,oriunde) }\end{array}$ \\
\hline 5 & $\begin{array}{l}\text { I feel that I am a member of this group. (belong3) } \\
\text { (Simt că sunt un membru al acestui grup.) }\end{array}$ \\
\hline 6 & $\begin{array}{l}\text { I am content to be part of this group. (morale3) } \\
\text { (Sunt mulțumit }(\breve{a}) \text { să fiu o parte a acestui grup.) }\end{array}$ \\
\hline
\end{tabular}


The translation of the scale in Romanian language followed the Forward Translation Design rules [16].

All students of $\mathrm{I}^{\text {st }}$ year completed this scale The average age is 19,6 years. Of the 241 students, 197 are male $(81,7 \%)$ and 44 are female $(18,3 \%)$. There were no significant differences between the two genders regarding the perception of the cohesion of the platoon they belong to. Responses were recorded on a 7-point, Likert-type scale with the following anchors: strongly disagree, quite, slightly, neither, slightly, quite, strongly agree.

\section{Analysis}

We used Amos 21 to perform the confirmatory factorial analysis. We applied the Maximum Likelihood method and analyzed the covariances of the six items of the scale. In figure 1 we present the model together with the standardized parameter estimates for our sample, which are all are statistically significant $(p<.05)$. The correlation between the two constructs belonging and morale - is high at $r=.89$. Five items of the scale are loading very well their respective construct; the item named morale2 is loading the construct above the minimal accepted standard $(>.60)$. These results are very similar to those reported by the creators of the scale - Bollen and Hoyle - and by Chin et al.

The measures for model fit [17] are presented in table 2 . The covariance matrix is presented in table 3 .

The Cronbach's alpha for belonging construct is 0.92 and for morale construct is 0.82 .
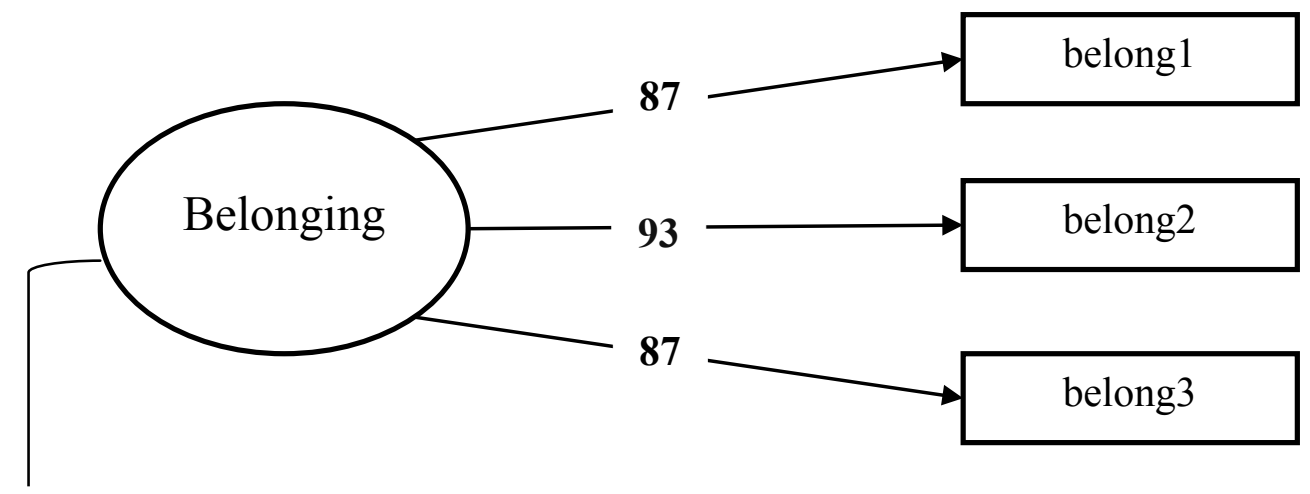

89
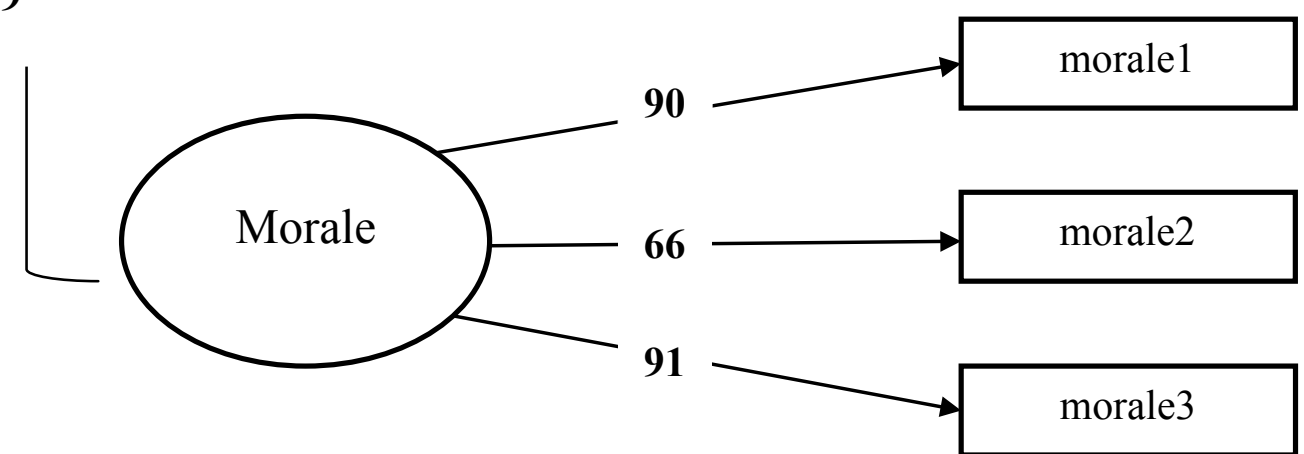

Figure 1: Two-Factor Model of the Perceived Cohesion Scale in Military Students Groups $(n=241)$

As in Chin et al. study, we also found a high correlation between the two constructs; therefore, we too assessed a single-factor model. This model is depicted 
in figure 2 and the fit indices are presented in table 2. We found that the fit indices are acceptable for the single-factor model, but the morale item loadings on a single factor are lower than on the corresponding construct from the two-factor model.

Table 2:Fit Assessment for Models of Perceived Cohesion Scale in Military Students Groups

\begin{tabular}{|c|c|c|c|}
\hline Statistic & Suggested value & $\begin{array}{c}\text { Single-Factor } \\
\text { Model }\end{array}$ & $\begin{array}{c}\text { Two-Factor } \\
\text { Model }\end{array}$ \\
\hline$\chi^{2}$ & & 96.06 & 41.84 \\
\hline$\chi^{2}$ significance & $\begin{array}{c}\mathrm{p} \geq 0.05 \\
\text { Not Applicable for large sample size }(>200)\end{array}$ & 0.000 \\
\hline $\mathrm{df}$ & $\leq 5.0$ & 9 & 8 \\
\hline$\chi^{2} / \mathrm{df}$ & $<.08$ & 10.67 & 5.23 \\
\hline RMSEA & $>.90$ & 0.20 & 0.13 \\
\hline GFI & $>.90$ & 0.88 & 0.94 \\
\hline AGFI & $\geq .95$ & 0.73 & 0.86 \\
\hline CFI & $\geq .95$ & 0.92 & 0.97 \\
\hline TLI & $\geq .95$ & 0.88 & 0.94 \\
\hline NFI & $\leq .05$ & 0.92 & 0.96 \\
\hline SRMR & & 0.039 & 0.026 \\
\hline
\end{tabular}

Table 3: Covariance matrix for Sample Data Set $(n=241)$

\begin{tabular}{|l|r|r|r|r|r|r|}
\hline \multicolumn{7}{|c|}{ Inter-Item Covariance Matrix } \\
\hline & belong1 & belong2 & belong3 & morale1 & morale2 & morale3 \\
\hline belong1 & .824 & & & & & \\
\hline belong2 & .660 & .829 & & & & \\
\hline belong3 & .705 & .712 & .952 & & & \\
\hline morale1 & .570 & .624 & .571 & .773 & & \\
\hline morale2 & .610 & .697 & .709 & .626 & 1.744 & \\
\hline morale3 & .554 & .654 & .643 & .682 & .783 & .896 \\
\hline
\end{tabular}

Since the constructs of the two-factor model are quite strongly correlated, we might think that they are not really distinct and that the six items of the scale are loading only one factor. If the difference between the values of $\chi^{2}$ obtained for the two models is insignificant, then those constructs are not distinct; if the difference is higher than the critical value of 3.84 , we can conclude that the two constructs are indeed distinct and the model with two factors is appropriate [18]. The data in table 2 shows a difference of 54.22 between the two values of $\chi^{2}$ (1df, $\left.p<.001\right)$. We can therefore conclude that the constructs in the solution with two factors are distinct. 


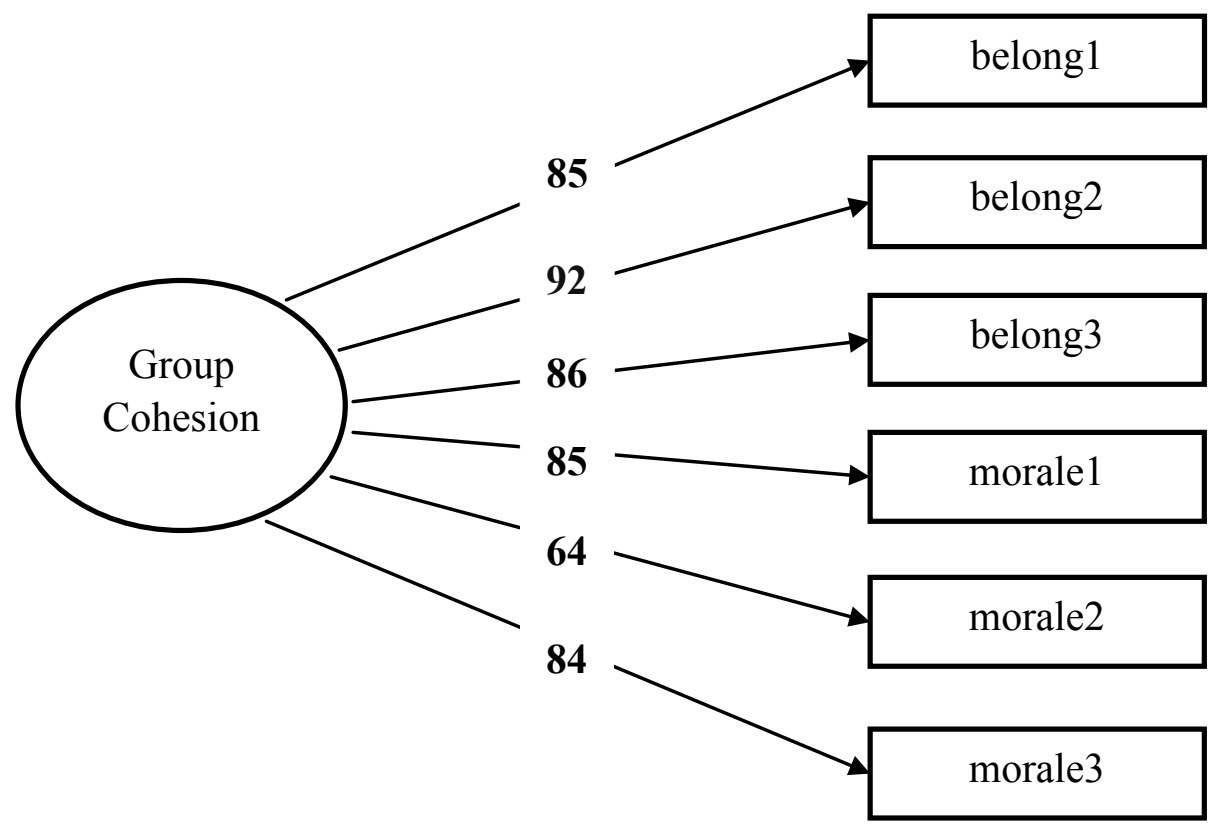

Figure 2: Single-Factor Model of the Perceived Cohesion Scale in Military Students Groups ( $n=241)$

\section{Conclusion}

Cohesion and morale are central concepts of modern military psychology. A small cohesive unit is not only effective in battles but it is also well integrated into the military organization it is part of and in the society it belongs to. D. Henderson very well captures the importance of cohesion for the modern army: "The nature of modern war indicates that small-unit cohesion is the only force capable of causing soldiers to expose themselves consistently to enemy fire in pursuit of an army's goals. The confusion, danger, hardship, and isolation of the modern battlefield have caused a pronounced deemphasis on strict orders, rote training, and coercive discipline. At the same time, there has been a significant shift downward in the control of soldiers in combat. Accompanying these changes has been increased emphasis on controlling soldiers through an internalization of values and operating rules congruent with the objectives, goals, and values of the organization." [19]

In terms of morale, its influence is felt in the way the soldiers solve their tasks. An increased level of morale is correlated with an increased level of efficiency and promptness, collaboration and cooperation amongst militaries, with a high level of mutual aid, of identification with the group, of self-esteem and group pride.

This research aimed at adapting the Perceived Cohesion Scale to military student groups. Exploratory analysis showed that this scale has the psychometric qualities required to successfully measure the level of cohesion and morale in this type of group. We intend to further adapt this scale to small units in various army specialties and to identify the phenomena associated with perceived cohesion.

\section{References}

[1] Carron, A.V., Brawley, L.R., Cohesion: Conceptual and measurement issues, Small Group Research, 31: 89 - 106, 2000. 
[2] McLeod, J., Von Treuer, K., Towards a Cohesive Theory of Cohesion, International Journal of Business and Social Research, [S.1.], vol.3, no 12, pp. 1-11, 2013. DOI:http://dx.doi.org/10.18533/ijbsr.v3i12.338

[3] Beal, D.J., Cohen, R.R., Burke, M.J., McLendon, C.L., Cohesion and performance in groups: A meta-analytic clarification of construct relations, Journal of Applied Psychology, 88: 989 - 1004, 2003.

[4] Carless, S.A., De Paola, C., The measurement of cohesion in work teams. Small Group Research, 31: $71-88,2000$.

[5] Andrews, M.C., Kacmar, K.M., Blakely, G.L., Bucklew, N.S., Group cohesion as an enhancement to the Justice-Affective commitment relationship, Group Organization Management, 33: 736-755, 2008.

[6] Kidwell,R.E., Mossholder, K.W., Bennett, N., Cohesiveness and organizational citizenship behaviour: A multilevel analysis using work groups and individuals, Journal of Management, 23: 775-779, 1997.

[7] Chen, C.H., Tang, Y.Y., Interdependence and organizational citizenship behaviour: Exploring the mediating effect of group cohesion in multilevel analysis, The Journal of Psychology, 143: 625-640, 2009.

[8] Orme, G.J., Kehoe, E.J., Pascoe, S.B., Gender integration into the combat arms: More unknowns than knowns for team cohesion, Australian Defence Force Journal, No. 200, pp. 59-67, 2016.

[9] MacCoun, R.J, Hix, W.M., Unit Cohesion and Military Performance, in National Defense Research Institute, Sexual Orientation and U.S. Military Personnel Policy: An Update of RAND's 1993 Study, Santa Monica, Calif.: RAND Corporation, MG-1056OSD, pp. 137-158, 2010.

[10] ibidem, p.139.

[11] Salas, E., Grossman, R., Hughes, A.M., Coultas, C.W., Measuring Team Cohesion: Observations from the Science, Human Factors, Vol. 57, No. 3, pp. 365 -374, 2015. DOI: $10.1177 / 0018720815578267$

[12] MacCoun, R.J., Hix, W.M., op.cit, p.155

[13] Bollen, K.A., Hoyle, R.H., Perceived cohesion: A conceptual and empirical examination. Social Forces, 69(2), 479-504,1990.

[14] Chin, W.W., Salisbury, W.D., Pearson, A.W., Stollak, M.J., Perceived cohesion in small groups: Adapting and testing the Perceived Cohesion Scale in a small-group setting, Small Group Research, 30(6), 751-766, 1999.

[15] Salisbury, W.D., Carte, T.A., Chidambaram, L., Cohesion in virtual teams: validating the perceived cohesion scale in a distributed setting, The Database for Advances in Information Systems, 37(2-3), 147-155, 2006.

[16] International Test Commission. The ITC Guidelines for Translating and Adapting Tests (Second edition), 2016.www.InTestCom.org

[17] Hooper, D., Coughlan, J., Mullen, M.R., Structural Equation Modelling: Guidelines for Determining Model Fit. The Electronic Journal of Business Research Methods, Volume 6 Issue 1/2008, pp. 53 - 60, available online at www.ejbrm.com

[18] Chin, W.W., Salisbury, W.D., Pearson, A.W., Stollak, M J., op. cit., p. 760

[19] Henderson, D. Cohesion. The Human Element in Combat. Leadership and Societal Influence in the Armies of the Soviet Union, the United States, North Vietnam, and Israel, National Defense University Press, Washington, DC, 1985, p. 4. 